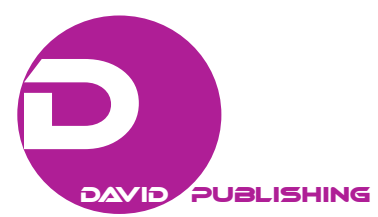

\title{
The Difference in a Patient Satisfaction Regarding the Reason of Admission to the Department of Surgery in General Hospital Ptuj, Slovenia
}

\author{
Teodor Pevec, Mihael Majerič, Matija Jakopanec \\ Surgery Department Ptuj, Ptuj, Slovenia
}

\begin{abstract}
Regional general hospitals in Slovenia admit both elective as well as acute patients. Is there a difference in patient satisfaction to the regarding the reason of admission? There were 88 patients included in this study: 52 elective and 36 acutely admitted. The national survey on patient satisfaction was used. With the Mann-Whitney U test, two groups were compared with the satisfaction scores and preformed a logistic regression analysis. Out of 100, the average total evaluated patient satisfaction score was 79 (SD 10.9) points. There is a statistically significant difference in the evaluated patient satisfaction score $(p=0.006)$ between the electively ( 82 points) and the acutely (75 points) admitted. Higher satisfaction is predicted by the patient satisfaction with the admission, the environment, and the manner of dismissal. Because this study included a small number of patients, authors will have to continue with the study to gain more credible results.
\end{abstract}

Keywords: patient satisfaction, measurement, hospital, organization

\section{Introduction}

An important goal of the overall medical care is the patient satisfaction, which is also reflected in the final outcome of the treatment (Gorenak \& Gorican, 2011). Today it is not enough to ensure health care, but it is also important that at the same time people ensure the safety of health care and continuously improve its quality. European accepted principles of quality and broader objectives, which have a great impact on society as follows: successfulness, safety, timeliness, effectiveness, equity, and focus on the patient (Yazbeck, Kociper, Mate, \& Marušič, 2006). Health care service quality and patient satisfaction are key elements of the European public healthcare systems agenda (Garci'a \& Bachiller, 2011). The essence of quality management is in a systematic continuous improvement of knowledge of the health care providers, improvement in the organizational processes of the health care services, working environments, and management. This is reflected in a rise of the successfulness of the treatment, increased availability of the health care services, better working conditions and environment, and most importantly as an increase in the health care security (Simčič, 2011).

Teodor Pevec, M.D., M.Sc., Ph.D. Student, Faculty of Economy and Marketing Maribor, Surgery Department Ptuj, Ptuj, Slovenia.

Mihael Majerič, M.D., Surgery Department Ptuj, Ptuj, Slovenia.

Matija Jakopanec, M.D., Surgery Department Ptuj, Ptuj, Slovenia.

Correspondence concerning this article should be addressed to Teodor Pevec, Potrceva 23-25, 2250 Ptuj, Slovenia. E-mail: teodor.pevec@sb-ptuj.si. 
Oliver (1997) noted that satisfaction is a general psychological state and is usually the result of emotional expectations and the experience from former shopping behaviors. In the service environment, the customer satisfaction has been seen as a special form of the customer attitude. It is a phenomenon of a post-purchase reflection on how much the customer likes or dislikes the service after experiencing it (Woodside, Frey, \& Daly, 1989) and it can also be defined as a fulfillment of the consumer's goals, which was experienced and described by the customers (Oliver, 2006). The consumer satisfaction is the fundamental of a consumer sovereignty (Choi, Cho, S. Lee, H. Lee, \& Kim, 2004). Satisfaction of a patient also affects the outcome of a medical practice. The patient satisfaction assessment is becoming an integral part of the strategic processes for the health care organizations (Reidenbach \& McClung, 1999).

Moreover, the patient satisfaction is a critical indicator for the health care service organizations. The providers of a medical service need to understand the patient's expectations and try to meet this (Lee, C. W. Chen, T. H. Chen, \& C. Y. Chen, 2010). For hospitals, the satisfied patients are important, because they are more likely to keep using the medical service, follow the prescribed treatment plan, maintain the relationship with a specific health care provider, and recommend the hospital to other users (Hekkert, Cihangir, Kleefstra, \& Van Den Berg, 2009). Undoubtedly, the patient's satisfaction is the passport to profitability in the hospital setting.

Both patients with an acute surgical problem as well as patients for an elective procedure are admitted to the surgical departments of all the general hospitals in Slovenia. The patients with an acute surgical problem are admitted because of a sudden change in their health status. On the acute disease or trauma as well as on its treatment, the patients are not prepared. In comparison, the patients admitted for an elective procedure are informed about their disease; they also had more time to prepare for the admission to the hospital while waiting for the procedure. This research wanted to know if there is a difference in the measured patient satisfaction, according to the reason of admission.

\section{Methods}

The research was made with the help of the national survey of the adult patient satisfaction with the health care treatment in the acute hospital (Retrieved from http://www.mz.gov.si/fileadmin/mz.gov.si/pageuploads/ mz_dokumenti/delovna_podrocja/zdravstveno_varstvo/kakovost/anketa_kakovosti_pacienti_2006/anketa_2007 _vprasalniki/NAIP_akutna_bolnisnica_2007.pdf).

The survey has six divisions. The first division measures the patients' satisfaction with the hospital admission. The second division is intended to assess the patients' satisfaction with the medical doctors. The third and the fourth divisions measure the patients' satisfaction with the hospital staff and with the medical treatment itself. The satisfaction with the hospital environment is assessed in the fifth division. The last, the sixth division, is intended to assess the patients' satisfaction with the hospital dismissal.

A five-point scale was used to assess the responses of the participants. If the participant entirely did not agree with the statement, he or she gave one point for the statement. If he or she chose five points, it meant that he or she entirely agrees with the statement. Estimates of two, three, or four points, expressed an intermediate level of agreement. The survey was divided to the participants by a researcher, who was not involved in the analysis. All the participants, who remained anonymous, were informed about the purpose of the survey, and that the participation in the survey will not affect their treatment. The sample population or the participants were the patients, who were admitted to the surgical department of general hospital Ptuj. 
They were admitted because of an acute surgical problem or for an elective surgical procedure. There were 88 patients included: 52 patients for an elective surgical procedure and 36 patients because of an acute surgical problem. There were 14 participants excluded from the research, because they did not complete the survey correctly or completely. The participants received the survey one-two days prior to their dismissal from the hospital.

The collected data were statistically analysed. They were calculated through the sample populations with descriptive statistics, the average total patient satisfaction score, the average satisfaction score of the patients who were admitted because of an acute surgical problem, and the average score of the patients who were admitted for an elective procedure. The two scores of the acutely admitted and the elective patients were compared with the Mann-Whitney U test. A multivariate logistic regression analysis was also performed. The data were analysed with SPSS 22.0.

The independent variables of this study were the six factors that influence the total patient satisfaction score: satisfaction with the admission to the hospital, satisfaction with the medical doctors, satisfaction with the medical staff, satisfaction with the overall medical treatment, and satisfaction with the hospital environment and hospital dismissal.

With the help of the logistic regression analysis, this paper wanted to confirm which of the six factors influences the total patient satisfaction score the most; if there is a difference between the acutely and electively admitted, how do they affect the patients' satisfaction scores of the acutely or electively admitted individually. The logistic regression analysis was performed for the upper quartile of the total patient satisfaction score.

\section{Results}

\section{Demographic Data Analysis}

There were 88 patients who participated in the study. Of the 88 participants, 52 were admitted because of an elective procedure and 36 because of an acute surgical problem. The mean age of the participants was 53.5 years. The participants of $20.5 \%$ had a primary education, $15.9 \%$ had a vocational education, $42 \%$ had a high-school education, $10.2 \%$ had a secondary or a higher education, and only $4.5 \%$ had a university or a college education. Five patients did not refer their educational status, which represent $5.7 \%$ of the participants. The participants of $37.5 \%$ answered that they were treated for the first time in general hospital Ptuj. The percentage of patients, who were treated more than once in the hospital, was $56.8 \%$. The participants of $5.7 \%$ did not answer to this question.

\section{Comparison of the Patient Satisfaction Score Between the Electively and Acutely Admitted}

The average overall patient satisfaction score was 79.07 points (SD 10.9 points). The comparison of the average or mean of the patient satisfaction score for the electively admitted patients to the mean score of acutely admitted patients reviled a statistically significant difference in favour for the patients, who were admitted for an elective procedure (Mann-Whitney $\mathrm{U}$ test $p=0.006$ ). Participants admitted for an elective procedure had a higher mean patient satisfaction score (82.01, SD 8.48 points) than the participants, who were admitted because of an acute surgical problem (74.84, SD 12.61 points). The results are shown in Figure 1. Also, the average patient satisfaction score with the standard deviation is shown. 


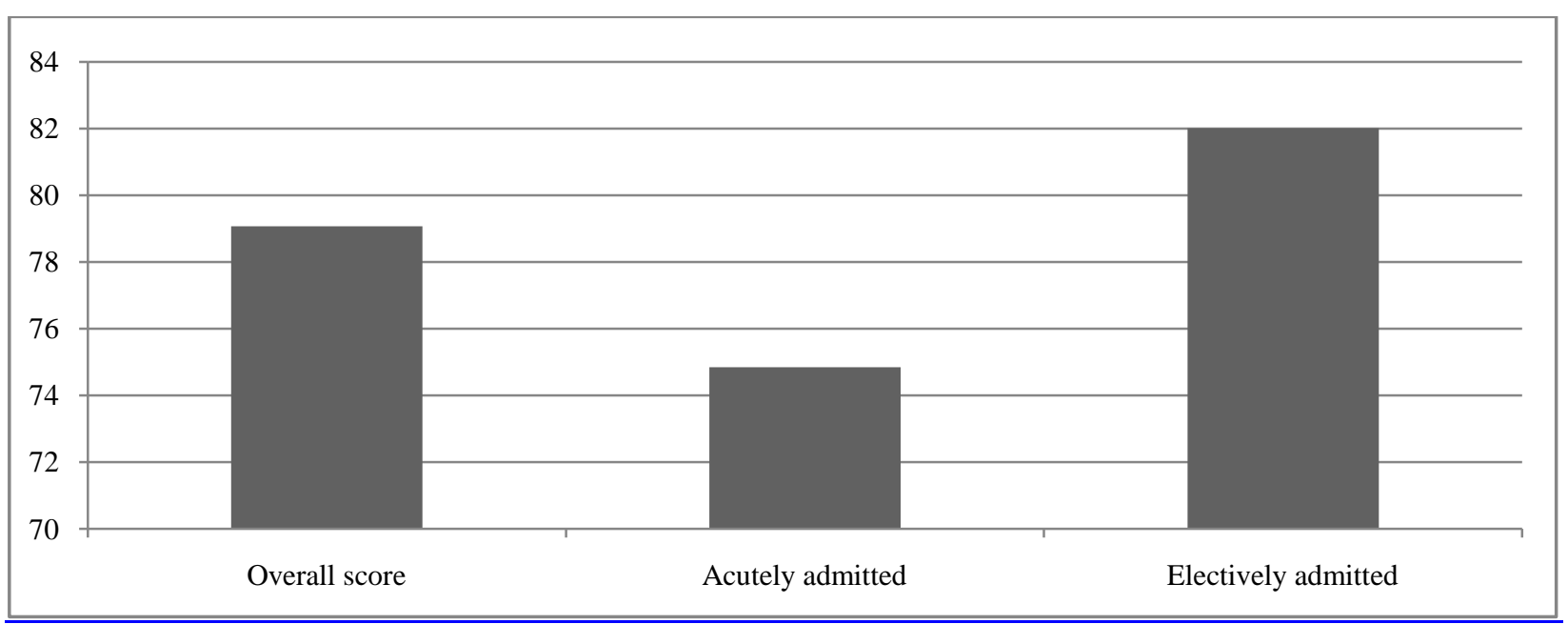

Figure 1. A comparisment of the average patient satisfaction scores between the groups, which were admitted because of an elective procedure or an acute surgical problem and the overall score of both groups.

Analysis of the Factors That Impact on the Overall Satisfaction Score and Comparisment of the Impact Factors Between Groups-Multivariate Analysis

Variables that predict higher overall patient satisfaction. This paper wanted to assess which of the variables from the six influences on the overall patient satisfaction score. With the help of the logistic regression for the independent variables: patient satisfaction with the hospital admission, patient satisfaction with the medical doctors, patient satisfaction with the hospital staff, and satisfaction with the medical treatment itself, hospital environment, and hospital dismissal, this paper made a model which predicts a higher total overall patient satisfaction score. Results are shown in Table 1.

The results show that a higher overall total patient satisfaction score can be predicted by three independent variables: patient satisfaction with the hospital admission, patient satisfaction with the hospital environment, and patient satisfaction with the dismissal from the hospital. With the logistic regression, it can accurately determine the upper (satisfied) quartile of patients for $88.6 \%$ of participants.

Table 1

Logistic Regression of Independent Variables, Which Statistically Significantly Determine the Upper (Satisfied) Quartile of the Overall Assessment of Satisfaction of the Respondents (Model: G [hi-kvadrat] = 55.373, 6 Degrees of Freedom, $p<0.001$ )

\begin{tabular}{lllllllll}
\hline & B & S.E. & Wald & df & Sig. & Exp(B) & lower & upper \\
\hline $\begin{array}{l}\text { Patient satisfaction with } \\
\text { the admission }\end{array}$ & 3.050 & 0.909 & 11.267 & 1 & 0.001 & 21.122 & 3.558 & 125.82 \\
$\begin{array}{l}\text { Patient satisfaction with } \\
\text { the hospital environment }\end{array}$ & 2.108 & 0.887 & 5.649 & 1 & 0.017 & 8.235 & 1.447 & 46.853 \\
$\begin{array}{l}\text { Patient satisfaction with } \\
\text { the manner of dismissal }\end{array}$ & 2.820 & 0.907 & 9.664 & 1 & 0.002 & 16.775 & 2.835 & 99.265 \\
Constant & -45.462 & $12,571.060$ & 0.000 & 1 & 0.997 & 0.000 & & \\
\hline
\end{tabular}

Variables that predict higher satisfaction in patients that were admitted for an elective procedure and in patients that were admitted because of an acute surgical problem. This paper also wanted to assess which of the six independent variables influences the patient satisfaction score for the patients that were 
admitted for an elective procedure and which of the six independent variables influences the patient satisfaction score for the patients that were admitted because of an acute surgical problem. With the help of logistic regression for the independent variables, it made a model which predicts a higher satisfaction score for the patients, who were admitted electively (Table 2 ) and for the patients who were admitted acutely (Table 3).

Table 2

Logistic Regression of Independent Variables, Which Statistically Significantly Determine the Upper (Satisfied) Quartile of the Assessment of Satisfaction for the Respondents, Who Were Admitted Electively (Model: $G$ [hi-kvadrat] $=15.758,3$ Degrees of Freedom, $p<0.001$ )

\begin{tabular}{lcccccccc}
\hline & B & S.E. & Wald & df & Sig. & Exp(B) & lower & upper \\
\hline $\begin{array}{l}\text { Patient satisfaction with } \\
\text { the admission }\end{array}$ & 2.408 & 1.136 & 4.493 & 1 & 0.034 & 11.117 & 1.199 & 103.073 \\
$\begin{array}{l}\text { Patient satisfaction with } \\
\text { the manner of dismissal }\end{array}$ & 1.651 & 0.770 & 4.591 & 1 & 0.032 & 5,211 & 1.151 & 23.590 \\
Constant & -4.095 & 1.241 & 10.887 & 1 & 0.001 & 0.017 & & \\
\hline
\end{tabular}

Table 3

Logistic Regression of Independent Variables, Which Statistically Significantly Determine the Upper (Satisfied) Quartile of the Assessment of Satisfaction for the Respondents, Who Were Admitted Acutely (Model: $G$ [hi-kvadrat $]=7.848,3$ Degrees of Freedom, $p<0.020$ )

\begin{tabular}{lllllllll}
\hline & B & S.E. & Wald & df & Sig. & Exp(B) & lower & upper \\
\hline $\begin{array}{l}\text { Patient satisfaction with } \\
\text { the admission }\end{array}$ & 1.695 & 0.845 & 4.020 & 1 & 0.045 & 5.444 & 1.039 & 28.533 \\
$\begin{array}{l}\text { Patient satisfaction with } \\
\text { the hospital environment }\end{array}$ & 2.457 & 1.199 & 4.197 & 1 & 0.040 & 11.667 & 1.112 & 122.381 \\
Constant & -0.847 & 0.488 & 3.015 & 1 & 0.082 & 0.429 & & \\
\hline
\end{tabular}

A higher satisfaction score in patients, who were admitted electively, can be predicted by the two independent variables: patient satisfaction with the hospital admission and patient satisfaction with the dismissal from the hospital. With the logistic regression, it can accurately determine the upper (satisfied) quartile of the electively admitted patients for $78.8 \%$ of participants.

A higher satisfaction score in patients, who were admitted because of an acute surgical problem, can be predicted by the two independent variables: patient satisfaction with the hospital admission and patient satisfaction with the hospital environment. With the logistic regression, it can accurately determine the upper (satisfied) quartile of the acutely admitted patients for $72.2 \%$ of participants.

\section{Discussion}

This study compared experiences of adult patients, or in other words, it compared their satisfaction according to the reason of admission and treatment. Patients were included, whose admission was planned and who were admitted for an elective procedure; patients were admitted because of an acute surgical problem, whose admission was not planned.

As a method for measuring and assessing patients' satisfaction, the national survey of the adult patient satisfaction with the health care treatment in the acute hospital was used. The national survey was introduced by the Ministry of Health in the year 2006. Hospitals began to use it in 2007. The survey allows comparability 
of the results among the departments and among hospitals.

The overall total patient satisfaction score was 79 out of 100 possible points. It can be seen that the overall total satisfaction score influences the manner of admission to the hospital, the hospital environment, and the dismissal, the most.

A great number of studies, where they also dealt with patient satisfaction, showed that the patients overexpress their satisfaction (Kersnik, 2001; Kovačič, 2008). The results of the study are comparable; they show a high rate of satisfaction regardless of the group of patients.

This research found a statistically significant difference in the satisfaction assessment between the group of patients that were admitted for the elective procedure ( 82 points) and the group of patients who were admitted acutely (75 points).

The findings are consistent with the hypothesis that greater use of elective hospital services is related to subsequently higher patient satisfaction (Fenton, Jerant, \& Franks, 2014). To find out, where is the difference between the groups, a multivariate regression analysis for each of the group was carried out. The results show that the manner of admission into and dismissal from the hospital has a great influence on the difference in favour of the electively admitted. The hospital environment also has a big effect on the patient satisfaction score of the acutely admitted patients. One of the explanations could be that the patients, who were admitted because of an acute surgical problem, have a strong emotional relation to the event that influenced them in the manner and that they were suddenly ripped out of their daily life. Because of this, they are more susceptible to the events that happen in the hospital. These patients usually also have a poorer health status, what could also influence them and their satisfactory score, because they are generally less satisfied. The patient that is ill or in the poor health status is under enormous stress, which also affects the relationship towards the health care providers and staff.

It can predict the manner of admission to the hospital, dismissal from the hospital and the hospital environment, has a great effect on the overall patient satisfactory score. Moreover, a very important factor, if not the most important factor, is communication and a respectful relationship between the health care providers and the patients (Gorenak \& Gorican, 2011; Lehmann, Fontaine, Borque, \& Cotte, 1988).

The satisfaction is measured, because the providers of the service like to compare with each other, and at the same time, the measurements give feedback information - how a user detects the services (Braunsberger \& Gates, 2002). The providers usually see the service from a different aspect in comparison with the users of the service. For the providers, the satisfaction with the service means achieving a certain level of standards and criteria. The users see the service through a subjective eye, which depends on their expectations and needs.

In the theory of non-confirmation (Newsome \& Wright, 1991), the patient compares his or her expectations to the actual properties of the service, which he or she detects during the treatment process. Because the patients who are admitted for an elective procedure have more time to mentally prepare, comparing to the patients who are admitted acutely. It could be predicted that the elective patients would have higher expectations. Nevertheless, the patients who were admitted because of an elective procedure were generally more satisfied than the acutely admitted patients.

A factor analysis reveals that a great influence on the satisfaction score played the factor of changing the date of admission, a great role also had the duration of the admission itself, and the possibility of an agreement for the admission date. Because the population sample of the study is small, it is hard to determine what would actually be the end result. 
Further on, the factor analysis revealed that for the participants and their satisfaction communicating about the questions of fear or worries about a certain diagnostic or treatment procedure also had a great role. It can see a difference between the acutely and electively admitted, where on the satisfaction of the acutely admitted patients, the communication with the doctors had more important role comparing to the other medical staff.

The analysis of the factors that influence the patients' satisfaction with the medical staff and nurses, revealed that ensuring privacy during nursing care, a respectful relationship and communicating between the staff and patients, had a great influence. The time of obtaining adequate assistance was also important.

Clarifying the need for a diagnostic or treatment procedure, assistance of the medical staff and insurance that their concerns are taken seriously are the factors that influence the satisfaction with the treatment itself. This holds true for both of the groups. It can also see that the noise caused from the hospital staff was one of the important factors that influenced the satisfaction with the hospital environment. For the patients to be satisfied with the manner of dismissal from the hospital, they had to receive relevant information about the warning signs on which they should take attention to. Weakness of this study is the fact that the sample was very little. It could be only a pilot study, with clear intention to be continued.

\section{Conclusions}

Assessment and measurement of a satisfaction should be compulsory for every department and hospital, especially in the light of competition among the institutions. Only the objectively measured results can show how they work and where they need to improve themselves. This study is made on a small population sample that is one of the reasons why authors should continue with the research to gain adequate results. Nevertheless, with this study, they have made a great model for further evaluating the patients' satisfaction with this work.

\section{References}

Braunsberger, K., \& Gates, R. H. (2002). Patients/enrolee satisfaction with healthcare and health plan. Journal of Consumer Marketing, 19(7), 557-590.

Choi, K. S., Cho, W. H., Lee, S., Lee, H., \& Kim, C. (2004). The relationships among quality, value, satisfaction and behavioral intention in health care provider choice: A South Korean study. Journal of Business Research, 57, 913-921.

Fenton, J. J., Jerant, F. A., \& Franks, P. (2014). Influence of elective versus emergent hospital admission in patient satisfaction. Journal of the American Board of Family Medicine, 27(2), 249-257.

Garcia, L. J., \& Bachiller, P. (2011). Dissecting hospital quality. Antecedents of clinical and perceived quality in hospitals. The International Journal of Health Planning and Management, 26(3), 264-281.

Gorenak, I., \& Gorican, A. (2011). Zadovoljstvo bolnikov v primarnem zdravstvu—Primer zdravstvenega doma Šmarje pri Jelšah. Zdrav Var, 50, 175-184.

Hekkert, K. D., Cihangir, S., Kleefstra, S. M., \& Van Den Berg, B. (2009). Patient satisfaction revisited: A multilevel approach. Social Science \& Medicine, 69(1), 68-75.

Kersnik, J. (2001). Multivariantna analiza zadovoljstva bolnikov z zdravnikom družinske medicine. Zdrav Vestn, 70, $381-386$.

Kovačič, P. (2008). Zadovoljstvo pacientov z zdravstvenimi storitvami (Diplomsko delo, Univerza v Ljubljani, Fakulteta za družbene vede).

Lee, W. I., Chen, C. W., Chen, T. H., \& Chen, C. Y. (2010). The relationship between consumer orientation, service value, medical care service quality and patient satisfaction: The case of a medical center in Southern Taiwan. African Journal of Business Management, 4(4), 448-458.

Lehmann, F., Fontaine, D., Borque, A., \& Cotte, L. (1988). Measurement of patient satisfaction: The Smith-Falvo patient-Doctor interaction scale. Can Fan Physican, 34, 2461-2645.

Ministrstvo za zdravje. (2007). Nacionalna anketa o izkušnjah odraslih pacientov $v$ akutni bolnišnici. Retrieved from http://www.mz.gov.si/fileadmin/mz.gov.si/pageuploads/mz_dokumenti/delovna_podrocja/zdravstveno_varstvo/kakovost/ank eta_kakovosti_pacienti_2006/anketa_2007_vprasalniki/NAIP_akutna_bolnisnica_2007.pdf 
Newsome, P. H. R., \& Wright, G. H. (1999). Patient management: A review of patient satisfaction: Concepts of satisfaction. British Dental Journal, 186, 161-165.

Oliver, R. L. (1997). Satisfaction: A behavioral perspective on the consumer. New York: McGraw-Hill.

Oliver, R. L. (2006). Customer satisfaction research. In R. Grover and M. Vriens (Eds.), The handbook of marketing research. Thousand Oaks: Sage Publications.

Reidenbach, R. E., \& McClung, G. W. (1999). Managing stakeholder loyalty: When satisfaction is just not enough. Marketing Health Services, 21, 21-29.

Simčič, B. (2011). Nacionalna strategija kakovosti $v$ zdravstvu. Pridobljeno na. Retrieved from http://www.mz.gov.si/fileadmin/mz.gov.si/pageuploads/kakovost/nacionalna_strategija_kakov_in_varn_2010-2015/Nacional na_strategija_kakovosti_in_varnosti_v_zdravstvu_2010-2015.pdf

Woodside, A. G., Frey, L., \& Daly, R. T. (1989). Linking service quality, customer satisfaction, and behavioral intension. Journal of Healthcare Marketing, 9(4), 5-17.

Yazbeck, A. M., Kociper, B., Mate, T., \& Marušič, D. (2006). Nacionalne usmeritve za razvoj kakovosti v zdravstvu. Ljubljana: Ministrstvo za zdravje. 